Article

\title{
Sustainable Entrepreneurs of the Future: The Interplay between Educational Context, Sustainable Entrepreneurship Competence, and Entrepreneurial Intentions
}

\author{
Sanna Joensuu-Salo *(D), Anmari Viljamaa and Elina Varamäki $\mathbb{D}$ \\ Seinäjoki University of Applied Sciences, 60320 Seinäjoki, Finland; anmari.viljamaa@seamk.fi (A.V.); \\ elina.varamaki@seamk.fi (E.V.) \\ * Correspondence: sanna.joensuu-salo@seamk.fi
}

check for

updates

Citation: Joensuu-Salo, Sanna,

Anmari Viljamaa, and Elina

Varamäki. 2022. Sustainable

Entrepreneurs of the Future: The Interplay between Educational

Context, Sustainable

Entrepreneurship Competence, and

Entrepreneurial Intentions.

Administrative Sciences 12: 23.

https://doi.org/10.3390/admsci 12010023

Received: 29 November 2021

Accepted: 29 January 2022

Published: 3 February 2022

Publisher's Note: MDPI stays neutral with regard to jurisdictional claims in published maps and institutional affiliations.

Copyright: (C) 2022 by the authors. Licensee MDPI, Basel, Switzerland. This article is an open access article distributed under the terms and conditions of the Creative Commons Attribution (CC BY) license (https:// creativecommons.org/licenses/by/ $4.0 /)$.

\begin{abstract}
The aim of this paper is to understand how sustainable entrepreneurship competence impacts entrepreneurial intentions in two educational contexts: in higher education and in secondary education. We applied the sustainable entrepreneurship framework, which includes six competencies of sustainable entrepreneurship, and the Theory of Planned Behavior. The data were gathered from seven European countries and consist of 486 responses from higher education students and 642 responses from secondary-level students. The results show that sustainable entrepreneurship competence (SEC) is a significant factor that can explain entrepreneurial intentions. It has a significant direct effect on entrepreneurial intentions in both educational contexts. Perceived behavioral control (PBC) moderates the relationship between SEC and entrepreneurial intentions; the effect of SEC decreases when PBC increases. The moderating effect was found only with higher education students, not with secondary-level students. This study demonstrates a connection between sustainable entrepreneurship competence and entrepreneurial intentions and contributes to a better understanding of the role of sustainable entrepreneurship competence in shaping students' aspirations for an entrepreneurial career in different educational contexts.
\end{abstract}

Keywords: entrepreneurial intentions; sustainable entrepreneurship competence; higher education; secondary education

\section{Introduction}

Sustainability issues have received widespread recognition throughout the last decade. Recently, the United Nations published 17 sustainable development goals to transform the world, which call for action by all countries to protect the planet and to promote prosperity (United Nations 2021). Policy makers are calling for more actions from educational institutes to prepare the mind-sets of future sustainable entrepreneurs (Fichter and Tiemann 2018). Thus, educational institutions are developing their curricula and operations to offer sustainability competence for these future change agents (Rieckmann 2012). Drawing upon prior research on competences, sustainable entrepreneurship competence can be defined as successful task performance and problem solving with respect to sustainable problems, challenges, and/or opportunities, and it consists of knowledge elements, skills, and attitudes (Barth et al. 2007; Wesselink et al. 2010; Ploum et al. 2018).

Entrepreneurs play an important role in sustainability development. They not only answer to legislative sustainability requirements of becoming more environmentally friendly, but they also assess both the environmental and social dimensions in core business strategies to seize opportunities in eliminating harm to the natural environment (Cohen and Winn 2007). Thus, entrepreneurs of the future need to be competent in sustainable entrepreneurship, which consists of different sub-competences related to systems thinking, diversity, foresight, norms, actions, interpersonal competence, and strategic management (Lans et al. 2014; Ploum et al. 2018). Young individuals possessing high levels of sustainable 
entrepreneurship competence may also have intentions to become entrepreneurs; however, little is known about the relationship between sustainable entrepreneurship competence and entrepreneurial intentions. This is an important issue, since policy makers are asking educational institutes to develop the entrepreneurship competence of young individuals, and society needs more entrepreneurs solving social and environmental problems. If educational institutes make an effort to develop sustainable competence in their students, will it result in higher entrepreneurial intentions and, thus, more entrepreneurs in society?

The aim of this paper is to understand how sustainable entrepreneurship competence impacts entrepreneurial intentions in two educational contexts: in higher education and in secondary education. As Thomassen et al. (2020) argued, there is a need to better understand the context when supporting entrepreneurial competence development. Sustainable entrepreneurship competence is needed for future change agents in entrepreneurial ventures. We apply the sustainable entrepreneurship framework developed by Ploum et al. (2018) in examining its impact on entrepreneurial intentions. In addition, we apply the Theory of Planned Behavior by Ajzen (1991), which is the most used model in entrepreneurial intention research (Maalaoui et al. 2018).

Context matters when designing and delivering education (Lave 2009). Thomassen et al. (2020) highlighted that, in entrepreneurship education, both what is learned and how it is learned is contextually dependent, and the context should be understood in entrepreneurial competence development. In this study, we examine how sustainable entrepreneurship competence explains the entrepreneurial aspirations of young people in the contexts of higher education and secondary education. Educational context represents the meso level of a context (see Thomassen et al. 2020). The educational contexts of higher education and secondary education differ, for example, in terms of objectives in learning outcomes, pedagogical practices, and student characteristics. Thus, the context matters in competence development.

In this study, we concentrate on sustainable entrepreneurship competence, the importance of which has risen during recent years, as society is facing a climate and environmental emergency. According to Ploum et al. (2018), competencies such as foresightfulness or anticipatory thinking, systems thinking, interdisciplinary work, and participation are considered key competencies in sustainability. Together, these can shape the ideas of entrepreneurship. Entrepreneurial intention has been seen as the first step in the entrepreneurial process (Liñán and Chen 2009), and one of the most used theories in the context of entrepreneurial intention research is the Theory of Planned Behavior (TPB) developed by Ajzen (1991). In $\mathrm{TPB}$, intentions precede behavior, and there are three conceptually independent antecedents of intentions: attitudes, subjective norm, and perceived behavioral control (Ajzen 1991). The validity of TPB in predicting various human behaviors has been confirmed by several researchers (e.g., Chu et al. 2016; Yang et al. 2018); however, there are many factors that can moderate the relationship between antecedents and intentions. Prior research in different research fields has shown that, for example, gender (Shin et al. 2020), individual interpretations (Wang et al. 2018), and prior experience (Hsieh et al. 2016) can moderate the relationship. In addition, the antecedents of TPB can have moderation effects (La Barbera and Ajzen 2021; Wan et al. 2018). More research is needed in the field of entrepreneurship. Lortie and Castogiovanni (2015) call for more research examining other antecedents in addition to the TPB antecedents affecting entrepreneurial intentions. Our study answers this call by examining the role of sustainable entrepreneurship competence in explaining entrepreneurial intentions, and how the antecedents of TPB moderate the relationship between sustainable entrepreneurship competence and intentions.

The specific objectives of this paper are: (1) to examine the direct effect of sustainable entrepreneurship competence on entrepreneurial intentions; (2) to examine the moderating effect of attitudes, perceived behavioral control, and subjective norm on the relationship between sustainable entrepreneurship competence and entrepreneurial intentions; and (3) to compare the impacts in two different contexts-in higher education and in secondary education. This study contributes to understanding the importance of sustainable en- 
trepreneurship competence in shaping aspirations for entrepreneurial careers, and how this is reflected in different educational contexts.

\section{Theoretical Framework and Hypothesis Development}

\subsection{Entrepreneurial Intention}

As Kuratko (2011) states, entrepreneurship is needed for economic growth, and entrepreneurs can enter, expand, and create entirely new markets for others. Thus, entrepreneurs have a key role in society. The intention to become an entrepreneur has been of interest to many scholars in recent decades. The history of intention research has its roots in social psychology, of which, the most used model has been the Theory of Planned Behavior (TPB), developed by Ajzen (1991). It has also been used in the context of entrepreneurial intention, which can be defined as "a self-acknowledged conviction by a person that they intend to set up a new business venture and consciously plan to do so at some point in the future" (Thompson 2009). This definition follows the ideas of Krueger and Carsrud (1993) who define entrepreneurial intentions as an individual's commitment to starting a new business. In these definitions, entrepreneurial intention is viewed as intentional and planned behavior.

While entrepreneurial intentions have been studied in various settings, Maalaoui et al. (2018) still see a growing interest in entrepreneurial intentions research. Thompson (2009) also states that despite the problems of loose definitions, entrepreneurial intention is still an important construct in entrepreneurship theory. In this study, entrepreneurial intention is seen as a student's commitment to starting a new business during or after studies. While entrepreneurial intention research has covered many issues, the concept of sustainability has only recently received attention. For example, Vuorio et al. (2018) examined the drivers of entrepreneurial intentions in sustainable entrepreneurship. They showed that attitude towards sustainability and perceived entrepreneurial desirability are positively related to sustainability-oriented entrepreneurial intentions. In this study, we concentrate on a student's sustainable entrepreneurship competence, and its relation to entrepreneurial intentions. Next, we introduce the sustainable entrepreneurship competence framework, the Theory of Planned Behavior, and the role of educational context.

\subsection{Sustainable Entrepreneurship Competence}

Sustainable entrepreneurship can be defined as "focused on the preservation of nature, life support, and community in the pursuit of perceived opportunities to bring into existence future products, processes, and services for gain, where gain is broadly construed to include economic and non-economic gains to individuals, the economy, and society" (Shepherd and Patzelt 2011, p. 142). Another definition by Albort-Morant et al. (2017, p. 2) is "the integration of conservation and development to ensure that modifications to the planet do indeed secure the survival and well-being of all people." Thus, sustainable entrepreneurs are key societal actors in solving social and environmental problems (Stubbs 2017). For solving these problems and challenges, entrepreneurs need sustainability competence. They need an ability to recognize sustainable entrepreneurial opportunities deriving from market imperfection, and the competence to utilize these opportunities.

Competence usually refers to knowledge, skills, and attitudes that are needed to successfully perform a task or key strengths that an individual possesses and demonstrates within a given context (Mulder et al. 2009; Mitchelmore and Rowley 2010). Entrepreneurial competencies have been seen as a wide range of characteristics, including personality traits, and specific knowledge and skills that are needed for successful business development (Gustomo et al. 2017). In this sense, sustainable entrepreneurship competence can also be viewed in light of knowledge, skills, and attitudes. There have been attempts to define and identify key competences of sustainable entrepreneurship. Masciarelli and Leonelli (2020) identify seven skills needed in sustainable entrepreneurship:

- Systems thinking (ability to identify, analyze, and cleverly combine the different firm domains); 
- $\quad$ Foresight thinking (ability to understand and predict the impact that decisions could have on environmental, social, and economic issues, and is generally combined with creativity, opportunity recognition, and innovativeness);

- Normative behavior (ability to map, apply, and reconcile sustainability values and targets related to the way the world should be);

- Embracing diversity and inter-disciplinary (ability to involve stakeholders and recognize the legitimacy of their viewpoints in the decision-making processes regarding environmental, social, and economic problems);

- Interpersonal (ability to motivate and make collaborative sustainability activities informal, i.e., communication and collaborative skills);

- Action (ability to be actively involved in responsible actions to improve the sustainability of systems);

- Strategic management (ability to design projects and implement interventions towards sustainable development practices).

These same competency areas have also been recognized in prior research (see Hesselbarth and Schaltegger 2014; Wesselink et al. 2015; Osagie et al. 2016; Lans et al. 2014). Ploum et al. (2018) tested a framework based on the seven competencies found by Lans et al. (2014), resulting in six competencies. Two competency areas suggested by Lans et al. (2014) were combined in the final framework. The final framework of Ploum et al. (2018) for sustainable entrepreneurship competence includes the following areas: (1) Strategic management competence and action competence, (2) Embracing diversity and interdisciplinary competence, (3) Systems thinking competence, (4) Normative competence, (5) Foresighted thinking competence, and (6) Interpersonal competence. However, the areas can be overlapping and correlate with one other.

According to Ploum et al. (2018) and Lans et al. (2014), strategic management competence refers to the ability to collectively design projects, implement interventions, transitions, and strategies for sustainable development practices, and action competence refers to the ability to be actively involved in responsible actions with the view of improving the sustainability of social-ecological systems. Embracing diversity and interdisciplinary competence is the ability to structure relationships and recognize relevant issues and the legitimacy of decision making in the context of environmental, social, and/or economic issues. Systems thinking competence refers to the ability to recognize and analyze relevant (sub)systems. Normative competence refers to the ability to map, apply, and fit together sustainability values, principles, and targets with internal and external stakeholders. Foresighted thinking competence refers to the ability to analyze, evaluate, and collectively envision the future, relating to the impact of local and/or short-term decisions on environmental, social, and economic issues on a global/cosmopolitan scale and in the long term. Interpersonal competence is the ability to motivate, enable, and facilitate collaborative sustainability activities and research.

Vuorio et al. (2018) argue that young adults today, compared with older generations, are more entrepreneurial and environmentally conscious, and entrepreneurship can be seen as a way to create value in terms of sustainability. This implies that individuals with high sustainable entrepreneurship competence can see entrepreneurship as a means of value creation and thus, have higher entrepreneurial intentions. Vuorio et al. (2018) showed that attitude towards sustainability and perceived entrepreneurial desirability are positively related to sustainability-oriented entrepreneurial intentions. Furthermore, Wagner (2012) found a positive relationship between sustainability orientation and sustainability-related entrepreneurial opportunities, even though the same relationship was not found with entrepreneurial intentions; hence, more research is needed. Based on the findings of Vuorio et al. (2018), we propose the following hypothesis:

Hypothesis 1 (H1). Sustainable entrepreneurship competence (SEC) is positively related to entrepreneurial intentions. 


\subsection{Theory of Planned Behavior (TPB)}

The Theory of Planned Behavior (TPB) is the most used model in entrepreneurial intentions research (Maalaoui et al. 2018). As entrepreneurial intention is considered to be intentional and reasoned, TPB model is well suited for studying entrepreneurial behavior (Krueger et al. 2000). The basic assumption of the theory is that intention predicts behavior, and the stronger the intention, the more likely the given behavior (Ajzen 1991). There are three antecedents of intention, namely perceived behavioral control (PBC), subjective norm, and attitudes towards the given behavior. PBC has a central role in the theory. Ajzen (1991, p. 183) defines it as "perception of the ease or difficulty of performing the behavior of interest", and if it is realistic, it can predict both intentions and actual behavior. Attitudes and subjective norm have indirect effect on behavior via intentions (Ajzen 1991).

Attitudes can be defined as a latent disposition of tendency to respond with some degree of favorableness or unfavorableness to a psychological object (Fishbein and Ajzen 1975). Attitudes can be negative, neutral, or positive, and have instrumental or experimental disposition (Fishbein 1967). Subjective norm refers to perceived social pressure from important others, which has an effect on the individual's intention to perform or not to perform the given behavior (Ajzen 1991). Ajzen (1991) highlights that for TPB to be valid, the measured concepts must correspond to the behavior that is predicted. The volitional control is important; if a person has complete control over the behavior, mere intention should be enough to predict the behavior. When volitional control decreases, the role of $\mathrm{PBC}$ as a predictor increases. Based on TPB, we suggest the following hypotheses:

Hypothesis 2 (H2). Perceived behavioral control, attitudes, and subjective norm are positively related to entrepreneurial intentions.

Prior research using TPB as a theoretical framework has shown that $\mathrm{PBC}$ can have moderation effects (Barua 2013; La Barbera and Ajzen 2021), as can subjective norm (Umeh and Patel 2004; Sawang et al. 2014; Wan et al. 2018), and attitudes (Conner and McMillan 1999). While there have been a number of studies examining TPB over the years, interaction hypothesis has received little attention (Yzer and van den Putte 2014). Thus, more empirical support is needed to understand the interaction effects of the antecedents of intention (Yzer 2012). Based on prior research, we test the following hypothesis:

Hypothesis 3 (H3). Perceived behavioral control, attitudes, and subjective norm moderate the relationship between SEC and entrepreneurial intentions.

\subsection{Educational Context}

As Welter et al. (2016) state, context is an important issue in entrepreneurship research. Thomassen et al. (2020) argue that we need to understand how context is related to entrepreneurial competence development and need to pay attention to context-specific issues when designing and executing entrepreneurship education. They further note that prior research on context and entrepreneurship education can be divided across three levels: the macro level (e.g., national context), the meso level (e.g., regional and university context), and micro level (e.g., course context).

In this study, we examine the educational context by comparing higher education and secondary education students. Educational context can be viewed as meso level. Prior research has found that entrepreneurial learning takes place at the local and regional context (Dohse and Walter 2012), and institutional factors (e.g., culture, leadership, strategy, purpose) are important elements in designing entrepreneurship education (Garavan et al. 2010). Higher education and secondary education have different purposes and objectives. For example, in the Finnish context, secondary education covers EQF levels 4 and 5, and higher education levels 6, 7, and 8. In this study, students studying at secondary-level are studying at levels 4 and 5, while students in higher education are studying at levels 6 and 7 . The levels have different requirements relating to knowledge, 
skills, and responsibility and autonomy (Europass-European Union 2021). If we look at the learning outcomes for level 4 based on Europass, knowledge is described as factual and theoretical knowledge in broad contexts within a field of work or study. Skills include cognitive and practical skills required to generate solutions to specific problems in a field of work or study, and responsibility and autonomy include self-management within the guidelines of work or study contexts that are usually predictable. In level 7, the requirements are much higher. Knowledge is highly specialized, skills are described as problem-solving skills in research and/or innovation in order to develop new knowledge, and students must manage and transform work or study contexts that are complex, unpredictable, and require new strategic approaches. Thus, developing entrepreneurial competencies in these different levels requires attention from educators and researchers, and educational context may have an effect on how SEC relates to entrepreneurial intentions. Based on prior research on contextual effects, we suggest the following hypothesis:

Hypothesis 4 (H4). The effect of SEC on entrepreneurial intentions, and the moderation effects of $S N, P B C$, and attitudes, differ across educational contexts.

\section{Data and Methods}

The data were gathered from seven European countries (Finland, Belgium, Netherlands, Spain, UK, Germany, and Italy) during the Erasmus+ project Sustainability-Driven Entrepreneurship in 2019 via a web-based survey. The research was implemented in two educational contexts: higher education and secondary education. The data consist of 486 responses from higher education students and 642 responses from secondary-level students. Table 1 presents the background information about the respondents. The majority of the respondents were from Finland or Belgium, and most of them were in the second year of their studies. Respondents represent different study fields; most of them were from the field of technology, communication, transport, social sciences, and business administration. The mean age of the respondents was 20 years, and $43 \%$ were women, $56 \%$ men, and $1 \%$ identified as other.

Table 1. Background characteristics of the respondents.

\begin{tabular}{|c|c|}
\hline Background & Percentage \\
\hline \multirow{5}{*}{ Educational level } & Higher education $43 \%$ \\
\hline & Secondary education $57 \%$ \\
\hline & Finland $57 \%$ \\
\hline & Belgium 17\% \\
\hline & Spain $10 \%$ \\
\hline \multirow[t]{7}{*}{ Country } & United Kingdom 4\% \\
\hline & Germany $4 \%$ \\
\hline & Italy $4 \%$ \\
\hline & Netherlands $4 \%$ \\
\hline & Humanities and Education $2 \%$ \\
\hline & Culture $6 \%$ \\
\hline & Natural Resources and Environment 8\% \\
\hline \multirow{6}{*}{ Year of study } & Tourism and Catering 7\% \\
\hline & Social services, Health and Sports 7\% \\
\hline & Technology, Communications and Transport 32\% \\
\hline & Social Sciences and Business Administration 16\% \\
\hline & $\mathrm{n} / \mathrm{a} 13 \%$ \\
\hline & Min 15 years \\
\hline \multirow[t]{3}{*}{ Age } & Max 63 years (only $3.6 \%$ over 30 ) \\
\hline & Mean 20 years \\
\hline & Women $43 \%$ \\
\hline \multirow[t]{2}{*}{ Gender } & Men $56 \%$ \\
\hline & Else $1 \%$ \\
\hline
\end{tabular}




\subsection{Variables}

Sustainable entrepreneurship competence (SEC) was measured with 22 items developed by Ploum et al. (2018). The original questionnaire of Ploum et al. consists of 27 items; however, in this study, some items were identified as too complex for secondary-level students and thus, omitted from the final scale. The SEC scale has six areas of sustainability competence: strategic management and action competence, diversity competence, systems thinking competence, normative competence, foresighted thinking competence, and interpersonal competence. In our data, SEC was treated as a one-factor-solution because Ploum et al. (2018) found that some of the sub-areas overlap and did not have enough discriminant validity. Our one-factor scale for SEC indicated good reliability with Cronbach's alpha of 0.97 (AVE 0.58). Factor loadings ranged from 0.66 to 0.83 .

Ajzen's (1991) Theory of Planned behavior was used in measuring entrepreneurial intention and the antecedent of intentions (attitudes, perceived behavioral control, and subjective norm). We applied items from Joensuu-Salo et al. (2015) in measuring the components of TPB. Entrepreneurial intentions were measured with eight items. Cronbach's alpha indicated good reliability for the scale (0.80). Perceived behavioral control was measured with four items with Cronbach's alpha of 0.71 . Attitudes towards entrepreneurship were measured with nine items. The items included instrumental (i.e., respected), experiential (i.e., interesting), and anticipated affect (oppressive) attitudes. Cronbach's alpha for attitudes was 0.79 . Subjective norm was measured with two sets: the first one measured belief items (the support individual receives from the most important persons) and the second one motivation to comply items referring to each of the belief questions. Belief items were measured with three items and motivation to comply with three items using the seven-point Likert scale. In statistical analysis, the recommendation from Ajzen (1991) was followed: each normative belief item was multiplied by the person's motivation to comply item with the referent in question. Coding -3 to +3 were used and a subjective norm index (ranging from -63 to +63 ) was created. As a result, subjective norm is directly proportional to the sum of the resulting products across the salient referents. Cronbach's alpha for belief items was 0.78 and for motivation to comply items was 0.79 . All the scales indicated sufficient reliability (over 0.70) based on Nunnally's (1978) recommendation.

Gender and entrepreneurial role models were used as control variables. Gender was operationalized as zero for women and one for male. Entrepreneurial role model was measured with a question "Have some of your closest people (parents, sisters, friends) worked as an entrepreneur?". In the analysis, yes was coded as one and no was coded as zero. Table 2 presents the correlations between the variables.

Table 2. Correlations between study variables.

\begin{tabular}{|c|c|c|c|c|c|c|}
\hline & 1. & 2. & 3. & 4. & 5. & 6. \\
\hline 1. EI & 1 & & & & & \\
\hline 2. $\mathrm{SN}$ & $0.213^{* * *}$ & 1 & & & & \\
\hline 3. PBC & $0.448^{* * *}$ & -0.008 & 1 & & & \\
\hline 4. $\mathrm{ATT}$ & $0.423^{* * *}$ & $0.127 * * *$ & $0.320^{* * *}$ & 1 & & \\
\hline 5. SEC & $0.367 * * *$ & $0.181^{* * *}$ & $0.316^{* * *}$ & & 1 & \\
\hline 6. GENDER & 0.047 & $-0.104^{* * *}$ & $0.151^{* * *}$ & 0.060 * & 0.038 & 1 \\
\hline $\begin{array}{l}\text { 7. ROLE } \\
\text { MODEL }\end{array}$ & $0.126^{* * *}$ & 0.006 & $0.145^{* * *}$ & $0.186^{* *}$ & $0.123^{* * *}$ & 0.005 \\
\hline
\end{tabular}

\subsection{Method}

Linear regression analysis was used to analyze the direct effect of SEC on entrepreneurial intentions. The moderating effect of PBC, subjective norm, and attitudes on the relationship between SEC and entrepreneurial intentions were tested using moderated multiple regression analysis, where variables were entered as predictors in a series of steps based on our hypotheses. Moderated multiple regression models allow the relationship between 
the dependent variable and an independent variable to depend on the level of another independent variable (Irwin and McClelland 2001). The moderated relationship is usually referred to as the interaction, which is included as an additional independent variable to the model. Two control variables were used: gender and entrepreneurial role models. The regression models were tested in two different contexts: higher education students and secondary-level students.

We used Kolmogorov-Smirnov and Shapiro-Wilk tests to test the normality of the scales, which showed that all the variables in our model were normally distributed. Podsakoff et al. (2003) state that common method biases may cause problems when data for both the predictor and criterion variable are obtained from the same person in the same measurement context, and using the same item context with similar item characteristics. They recommend using additional statistical remedies to control for the effect. One of the ways to explore possible common method bias is to use Harman's single factor test. We loaded all of the studied variables into an exploratory factor analysis and examined unrotated factor solution. The basic assumption is that if a substantial amount of common method variance is present, either a single factor will emerge or one general factor will account for the majority of the covariance among the measures. Kaiser's criterion for retention of factors was followed. The Kaiser-Meyer-Olkin measure of sampling adequacy indicated that our sample size was large enough for the factor analysis $(\mathrm{KMO}=0.96)$. Factor analytic results indicated the existence of several factors with eigenvalues greater than 1.0. The first factor accounted for 29.8 percent of the variance. Since several factors, as opposed to one single factor, were identified and since the first factor did not account for the majority of the variance, a substantial amount of common method variance does not appear to be present.

\section{Results}

The results of linear regression are shown in Table 3 for higher education students and in Table 4 for secondary-level students. The first models include only control variables. The only significant factor explaining the entrepreneurial intentions of students was role model (Table 2). The first model explains 18 percent of the variance in entrepreneurial intentions of higher education students and 10 percent of the variance in entrepreneurial intentions of secondary-level students. In the second model, sustainable entrepreneurship competence (SEC) was added as an independent variable. Results show that SEC is a significant factor explaining entrepreneurial intentions. It has a significant direct effect on entrepreneurial intentions in both educational contexts, with higher education students $(\beta=0.27 ; p<0.001)$ and secondary-level students $(\beta=0.42 ; p<0.001)$. Hypothesis 1 is supported. The impact of SEC remains when the components of TPB are added in model 3 . For higher education students, perceived behavioral control is the most important factor explaining entrepreneurial intentions $(\beta=0.36 ; p<0.001)$ followed by attitudes $(\beta=0.22 ; p<0.001)$. However, subjective norm is not a significant predictor of intentions among higher education students. The whole model explains 27 percent of the variance in entrepreneurial intentions. For secondary-level students, the best predictor of intentions is also perceived behavioral control $(\beta=0.40 ; p<0.001)$. In addition, attitudes $(\beta=0.24 ; p<0.001)$ and subjective norm ( $\beta=0.16 ; p<0.001)$ are both significant factors explaining entrepreneurial intentions. The whole model explains 45 percent of the variance in entrepreneurial intentions. These results provide full support for hypothesis 2 with secondary-level students, and partial support with higher education students. 
Table 3. Results for higher education students.

\begin{tabular}{|c|c|c|c|c|}
\hline & Model 1 & Model 2 & Model 3 & Model 4 \\
\hline Constant & $3.411(0.095) * * *$ & $2.250(0.207) * * *$ & $0.414(0.273)$ & $-0.343(0.971)$ \\
\hline \multirow{2}{*}{ Gender } & $0.122(0.098)$ & $0.099(0.095)$ & $-0.058(0.088)$ & $-0.067(0.087)$ \\
\hline & $\beta 0.056$ & $\beta 0.046$ & $\beta-0.027$ & $\beta-0.031$ \\
\hline \multirow{2}{*}{ Role models } & $0.306(0.103)^{* *}$ & $0.231(0.100) *$ & $0.102(0.090)$ & $0.090(0.090)$ \\
\hline & $\beta 0.134$ & $\beta .101$ & $\beta 0.045$ & $\beta 0.039$ \\
\hline \multirow{2}{*}{ SEC } & & $0.295(0.047) * * *$ & $0.092(0.046)$ * & $0.254(0.224)$ \\
\hline & & $\beta 0.274$ & $\beta 0.086$ & $\beta .236$ \\
\hline \multirow{2}{*}{ PBC } & & & $0.383(0.047)^{* * *}$ & $0.877(0.178) * * *$ \\
\hline & & & $\beta 0.360$ & B 0.825 \\
\hline \multirow{2}{*}{$\mathrm{ATT}$} & & & $0.277(0.053) * * *$ & $0.033(0.207)$ \\
\hline & & & $\beta 0.218$ & $\beta 0.026$ \\
\hline \multirow{2}{*}{$\mathrm{SN}$} & & & $0.004(0.002)$ & $-0.013(0.010)$ \\
\hline & & & $\beta 0.066$ & $\beta-0.205$ \\
\hline \multirow{2}{*}{$\mathrm{PBC} \times \mathrm{SEC}$} & & & & $-0.114(0.040) * *$ \\
\hline & & & & B -0.733 \\
\hline \multirow{2}{*}{$\mathrm{ATT} \times \mathrm{SEC}$} & & & & $0.060(0.048)$ \\
\hline & & & & $\beta 0.382$ \\
\hline \multirow{2}{*}{$\mathrm{SN} \times \mathrm{SEC}$} & & & & $0.004(0.002)$ \\
\hline & & & & $\beta 0.271$ \\
\hline F statistics & $5.472 * *$ & $16.970^{* * *}$ & $31.146^{* * *}$ & $22.562 * * *$ \\
\hline Adjusted $\mathrm{R}^{2}$ & 0.018 & 0.090 & 0.273 & 0.287 \\
\hline F change & & $39.097^{* * *}$ & $41.065^{* * *}$ & $4.155^{* *}$ \\
\hline
\end{tabular}

${ }^{*} p<0.05,{ }^{* *} p<0.01,{ }^{* * *} p<0.001$, Standard errors are reported in parentheses.

Table 4. Results for secondary-level students.

\begin{tabular}{|c|c|c|c|c|}
\hline & Model 1 & Model 2 & Model 3 & Model 4 \\
\hline Constant & $3.618(0.086) * * *$ & $2.074(0.157)^{* * *}$ & $0.321(0.188)$ & $0.202(0.589)$ \\
\hline Gender & $0.055(0.084)$ & $0.026(0.076)$ & $-0.019(0.063)$ & $-0.019(0.063)$ \\
\hline Gender & $\beta 0.026$ & $\beta 0.012$ & $\beta-0.009$ & $\beta-0.009$ \\
\hline & $0.239(0.085)^{* *}$ & $0.127(0.078)$ & $0.065(0.064)$ & $0.064(0.064)$ \\
\hline Role models & $\beta 0.112$ & B 0.060 & $\beta 0.031$ & B 0.030 \\
\hline SEC & & $\begin{array}{c}0.391(0.034)^{* * *} \\
\beta 0.415\end{array}$ & $\begin{array}{c}0.153(0.031)^{* * *} \\
\beta 0.162\end{array}$ & $\begin{array}{c}0.185(0.139) \\
\beta 0.196\end{array}$ \\
\hline PBC & & & $\begin{array}{c}0.410(0.034)^{* * *} \\
\beta 0.399\end{array}$ & $\begin{array}{c}0.374(0.121) * * \\
\beta .364\end{array}$ \\
\hline ATT & & & $\begin{array}{c}0.253(0.035) * * * \\
\beta 0.235\end{array}$ & $\begin{array}{c}0.303(0.132) * \\
\beta 0.281\end{array}$ \\
\hline SN & & & $\begin{array}{c}0.009(0.002)^{* * *} \\
\beta 0.163\end{array}$ & $\begin{array}{c}0.012(0.007) \\
\beta 0.221\end{array}$ \\
\hline $\mathrm{PBC} \times \mathrm{SEC}$ & & & & $\begin{array}{c}0.008(0.027) \\
\beta 0.052\end{array}$ \\
\hline $\mathrm{ATT} \times \mathrm{SEC}$ & & & & $\begin{array}{c}-0.012(0.030) \\
\beta-0.091\end{array}$ \\
\hline $\mathrm{SN} \times \mathrm{SEC}$ & & & & $\begin{array}{c}-0.001(0.001) \\
\beta-0.061\end{array}$ \\
\hline F statistics & $4.122 *$ & $46.369^{* * *}$ & $86.673^{* * *}$ & $57.607^{* * *}$ \\
\hline Adjusted $\mathrm{R}^{2}$ & 0.010 & 0.178 & 0.451 & 0.448 \\
\hline F change & & $129.171^{* * *}$ & $104.013^{* * *}$ & 0.170 \\
\hline
\end{tabular}

${ }^{*} p<0.05,{ }^{* *} p<0.01,{ }^{* * *} p<0.001$, Standard errors are reported in parentheses.

Model 4 tests the possible moderator effects by adding interaction terms to the model. Results show that PBC moderates the relationship between SEC and entrepreneurial intentions with higher education students. The effect of SEC decreases when PBC increases. The moderating effect was found only with higher education students, not with secondarylevel students. There were no moderating effect of attitudes or subjective norm found 
on the relationship between SEC and entrepreneurial intentions. Hypothesis 3 is thus partially supported.

The educational context matters. There are several differences between these two contexts. First, the direct impact of SEC is even stronger with secondary-level students than with higher education students. Second, subjective norm explains entrepreneurial intentions of secondary-level students, but not of higher education students. Third, the whole model has more explanation power with secondary-level students compared with higher education students. Finally, the moderating effect of PBC on the relationship between SEC and entrepreneurial intentions was found only with higher education students. These results provide support for hypothesis 4 .

Figure 1 presents the final model for this study. All variables in the model have a direct and positive relationship with entrepreneurial intentions. However, it should be noted that the positive relationship between subjective norm and EI was found only with secondary-level students. PBC moderates the effect of SEC on entrepreneurial intentions; however, the moderating effect of PBC was found only with higher education students.

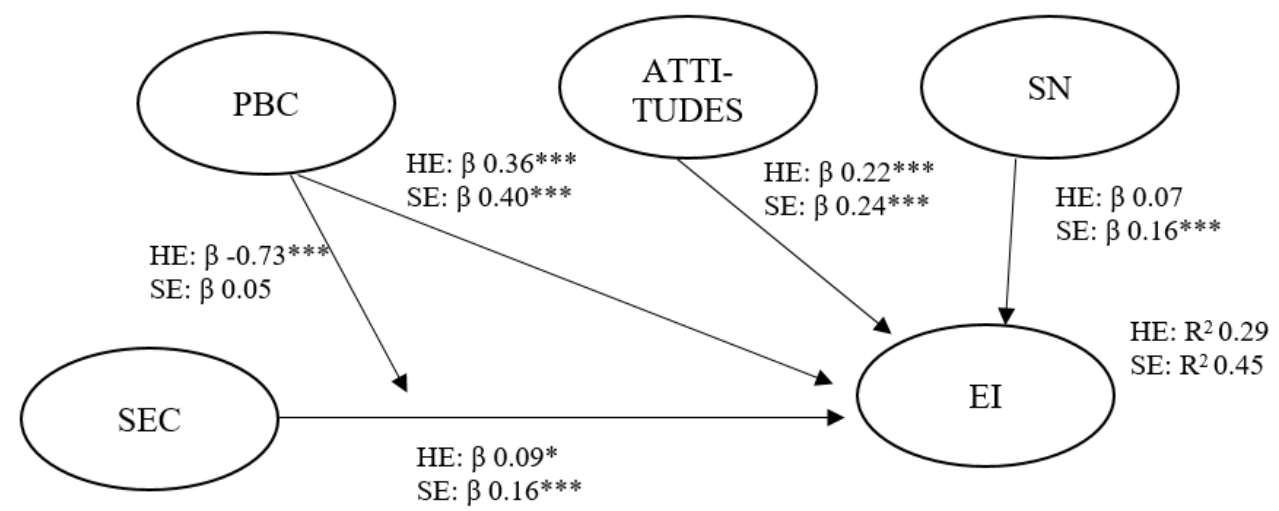

Figure 1. Final model ( $\mathrm{HE}=$ higher education; $\mathrm{SE}=$ secondary education, $\mathrm{SEC}=$ sustainable entrepreneurship competence, $\mathrm{PBC}=$ perceived behavioral control, $\mathrm{SN}=$ subjective norm, $\mathrm{EI}=$ entrepreneurial intentions. ${ }^{*} p<0.05,{ }^{* * *} p<0.001$.

\section{Discussion}

The first objective of this study was to examine the direct effect of sustainable entrepreneurship competence on entrepreneurial intentions. The results show that sustainable entrepreneurship competence (SEC) is a significant factor explaining entrepreneurial intentions of both higher education students and secondary-level students. The results extend the work of Ploum et al. (2018) on sustainable entrepreneurship competence by applying the suggested framework to a wider setting, as the original testing was carried out solely with students who had indicated interest in sustainable entrepreneurship. Here, sustainable entrepreneurship competence is connected to entrepreneurial intention and its antecedents.

Our findings support the arguments of Vuorio et al. (2018)—individuals with high sustainable competence can see entrepreneurship as a way to build a better world. Vuorio et al. (2018) examined how attitudes of sustainability predict sustainability-oriented entrepreneurial intentions and found a positive relationship. In this study, we examined general entrepreneurial intentions, not specific sustainability-oriented entrepreneurial intentions. However, our results suggest that individuals with high sustainable entrepreneurship competence see entrepreneurship in general as a prospective career choice. Our results differ from the findings of Wagner (2012), who found that sustainability orientation was not related to entrepreneurial intentions but had a positive relationship with sustainabilityrelated entrepreneurial opportunities. This controversial result may be caused by the fact that sustainability orientation and sustainable entrepreneurship competence are different concepts. Wagner (2012) defines sustainability orientation as "the level of social 
and environmental concerns of an individual". This differs greatly from sustainable entrepreneurship competence, which includes the skills, attitudes, and knowledge needed in sustainable entrepreneurship. It seems that general concerns about nature in itself do not lead to entrepreneurial intentions, but if an individual has the required competence for successful sustainable entrepreneurship, entrepreneurial intentions will follow.

The second objective was to examine the moderating effect of attitudes, perceived behavioral control, and subjective norm on the relationship between sustainable entrepreneurship competence and entrepreneurial intentions. The results show that no moderating effect of attitudes or subjective norm was found, but perceived behavioral control moderated the effect of sustainable entrepreneurship competence on entrepreneurial intentions among higher education students. Prior research has shown that perceived behavioral control can moderate the effect of other antecedents in TPB. For example, La Barbera and Ajzen (2021) showed that when perceived behavioral control increases, the strength of the relationships between attitude and intentions, and between subjective norm and intentions increase. Moreover, Martinez and Lewis (2016) found the same moderating effect of perceived behavioral control on the association between attitude and intentions. Thus, it seems that perceptions of control can determine how and to what extent different factors influence intentions. In this study, perceived behavioral control, i.e., the individual's perception on his/her capability to act as an entrepreneur, has an influence on the relationship between sustainable entrepreneurship competence and intentions. When perceived behavioral control increases, the effect of sustainable entrepreneurship competence decreases. This implies that the influence of SEC on entrepreneurial intentions is stronger for individuals with low scores of PBC, and lower for individuals with high scores of PBC. Thus, high PBC somewhat overrides the effect of SEC. However, this interaction effect was not found with secondary-level students. It should be noted that we did not examine the moderation effect of PBC on the relationships between attitudes and intentions or SN and intentions as did La Barbera and Ajzen (2021). Instead, we found the moderation effect of PBC on the relationship between SEC and entrepreneurial intentions. It seems that PBC has a major role in TPB. It has a direct influence on intentions, and it can also moderate the impact of other factors than SN or attitudes on intentions, such as in this case, the impact of SEC. The reason this was significant only with higher education students may be related to contextual factors. Higher education students are older and may have more theoretical knowledge than students in secondary education. If higher education students have high levels of SEC, they can see entrepreneurship as a potential way to solve environmental challenges despite perceptions of low control. Another aspect is the concept of self-efficacy, as one of the main mechanisms in the regulatory process is an individual's belief about their personal efficacy. This perceived self-efficacy relates to capabilities to mobilize the motivation, cognitive resources, and courses of action needed to exercise control. These can be instilled and strengthened by mastery experiences, modeling, social persuasion, and physiological states (Wood and Bandura 1989). Bandura (1994) defines perceived self-efficacy as "people's beliefs about their capabilities to produce designated levels of performance that exercise influence over events that affect their lives". These self-beliefs determine the level of motivation; people with strong beliefs in their capabilities put greater effort into their actions despite challenges. These beliefs have an effect on how we feel, think, motivate ourselves and behave. While SEC is a separate concept to self-efficacy, it may have some connection to it. In this study, students evaluated their competence in sustainability, and the higher this evaluation was, the less effect PBC had on entrepreneurial intentions. Thus, despite challenges of control, high SEC increases entrepreneurial intentions.

The third objective related to the educational context. The results show that educational context has an effect on the model relationships. The relationship between sustainable entrepreneurship competence and entrepreneurial intentions is stronger with secondarylevel students, and perceived behavioral control does not have a moderating effect on the relationship. This implies that for secondary-level students, sustainable entrepreneurship competence is a powerful predictor of entrepreneurial intentions. The students of secondary 
education are younger than students in higher education. Hence, age may have some effect, but so can institutional factors such as learning objectives and career counseling. Especially in vocational education, the students are equipped with more practical skills than theoretical skills. With these practical skills and high sustainable entrepreneurship competence, young individuals may see entrepreneurship as a way to create value. Prior research has also highlighted the effect of context in entrepreneurship education research (Thomassen et al. 2020). As Dohse and Walter (2012) argue, the research on entrepreneurial intentions should pay attention to the contextual framework, and especially to the access of knowledge resources. Different educational levels give access to different kinds of knowledge resources; thus, our results support the arguments of Dohse and Walter (2012).

Subjective norm predicts the entrepreneurial intentions of secondary-level students but not of higher education students. Subjective norm refers to the support of the most important persons relating to a specific behavior, such as becoming an entrepreneur. It may be that the support of the most important persons is more important for younger adults than individuals in higher education. Our results suggest that, concerning entrepreneurial intentions, secondary-level students need support from parents, friends, or spouses, and the stronger the support, the stronger the intention to become an entrepreneur. The model explains 45 percent of the variance in entrepreneurial intentions among secondary-level students and 29 percent among higher education students. It is interesting that prior research has shown that subjective norms are better predictors of intentions in more collectivist cultures compared with individualistic cultures (Cho and Lee 2015), and with individuals with collectivist orientation (Ybarra and Trafimow 1998). We did not measure the collectivist/individualistic values of students, but this raises questions for future research in terms of educational context and values. Overall, our findings suggest that context should be considered when testing different theories in entrepreneurship education research. The strength of the suggested associations may vary depending on the educational context, and the theory may work better in some context compared with another.

Interestingly, gender was not a significant factor. This is in contrast with prior research, which has shown higher entrepreneurial intentions (Nowiński et al. 2019) and more startup behavior (Joensuu-Salo et al. 2020) for men compared with women. While our result cannot override the many results of prior research, one hopeful interpretation is that the cultural structures inhibiting women's sense of agency are weakening, affording more leeway for women's entrepreneurial intentions to flourish. If that is indeed the case, our young respondents may yet escape the full impact of the structures that have worked against women's expression of their entrepreneurial potential.

\section{Conclusions}

As a theoretical contribution, our results suggest that sustainable entrepreneurship competence is related to entrepreneurial intentions, but the strength of the relationship can vary depending on the educational context. Educational context can also be viewed as a knowledge context, which should receive more attention according to Dohse and Walter (2012). Educational institutions have different ecosystems that connect students to knowledge, and this may have an effect on an entrepreneurial event. In any case, our results suggest that sustainable entrepreneurship competence is an important factor affecting the entrepreneurial intentions of students. This has double the number of advantages. First, by developing the sustainable entrepreneurship competence of students, society will have more individuals interested in entrepreneurship. Second, these future entrepreneurs will have more competence in solving societal end environmental problems.

The moderating effect of PBC should be taken into account in future research, as it can have an effect on the other antecedents of intentions. This is also strongly suggested by La Barbera and Ajzen (2021) in their recent research. PBC has both significant direct and moderating effects. Future research should test the whole model with a followup measure of behavior. In terms of future avenues of research, it would be important to examine how sustainable entrepreneurship competence can be developed through 
educational efforts. Prior research on sustainable entrepreneurship has mainly concentrated on how sustainable entrepreneurship relates to sustainable development, thus focusing on innovation issues (see Moya-Clemente et al. 2021). The perspective of developing sustainable entrepreneurship competence has not received so much attention, which should be taken into account in future research.

As a practical implication, the results suggest that sustainable entrepreneurship competence works well as a diagnostic tool for competencies related to venturing in general, not just in sustainability-related ventures. Furthermore, focusing on developing the skills associated with the competence is likely to support the entrepreneurial intentions of students. This study offers promising results for educational institutes. By developing the sustainable entrepreneurship competence of students, institutes can at the same time boost entrepreneurial intentions. Society needs more entrepreneurs to solve societal and environmental challenges, and educational institutes can contribute by focusing on the sustainable competence development of students.

This study naturally has some limitations. It did not test the whole model with a behavior variable, and the sample has an overrepresentation of Finnish students. Thus, the cultural context should be taken into account in future research.

Author Contributions: Conceptualization, S.J.-S., A.V. and E.V.; methodology, S.J.-S.; formal analysis, S.J.-S.; investigation, S.J.-S.; resources, E.V.; data curation, S.J.-S.; writing—original draft preparation, S.J.-S. and A.V.; writing-review and editing, S.J.-S., A.V. and E.V.; visualization, S.J.-S.; supervision, E.V.; project administration, A.V.; funding acquisition, E.V. All authors have read and agreed to the published version of the manuscript.

Funding: This research received no external funding.

Institutional Review Board Statement: The study was conducted in accordance with the Declaration of Helsinki, and approved by the Ethics Committee of Seinäjoki University of Applied Sciences.

Informed Consent Statement: Informed consent was obtained from all subjects involved in the study.

Data Availability Statement: Data available on request due to restrictions of privacy. The data presented in this study are available on request from the corresponding author. The data are not publicly available due to confidentiality.

Conflicts of Interest: The authors declare no conflict of interest.

\section{References}

Ajzen, Icek. 1991. The theory of planned behavior. Organizational Behavior and Human Decision Processes 50: 179-211. [CrossRef]

Albort-Morant, Gema, Jörg Henseler, Antonio Leal-Millán, and Gabriel Cepeda-Carrión. 2017. Mapping the field: A bibliometric analysis of green innovation. Sustainability 9: 1011. [CrossRef]

Bandura, Albert. 1994. Self-efficacy. In Encyclopedia of Human Behavior, Volume 2. Edited by Vilayanur Subramanian Ramachaudran. New York: Academic Press, pp. 71-81.

Barth, Matthias, Jasmin Godemann, Marco Rieckman, and Ute Stoltenberg. 2007. Developing key competences for sustainable development in higher education. International Journal of Sustainability in Higher Education 8: 416-30. [CrossRef]

Barua, Promotosh. 2013. The Moderating Role of Perceived Behavioral Control: The Literature Criticism and Methodological Considerations. International Journal of Business and Social Science 4: 57-59.

Cho, Hichang, and Jae-Shin Lee. 2015. The influence of self-efficacy, subjective norms, and risk perception on behavioral intentions related to the H1N1 flu pandemic: A comparison between Korea and the US. Asian Journal of Social Psychology 18: 311-24. [CrossRef]

Chu, Shu-Chuan, Hsuan-Ting Chen, and Yongjun Sung. 2016. Following brands on Twitter: An extension of theory of planned behavior. International Journal of Advertising 35: 421-37. [CrossRef]

Cohen, Boyd, and Monica Winn. 2007. Market imperfections, opportunity and sustainable entrepreneurship. Journal of Business Venturing 22: 29-49. [CrossRef]

Conner, Mark, and Bryan McMillan. 1999. Interaction effects in the theory of planned behaviour: Studying cannabis use. British Journal of Social Psychology 38: 195-222. [CrossRef]

Dohse, Dirk, and Sascha Walter. 2012. Knowledge context and entrepreneurial intentions among students. Small Business Economics 39: 877-95. [CrossRef]

Europass-European Union. 2021. Description of the Eight EQF Levels. Available online: https:/ / europa.eu/europass/fi/descriptioneight-eqf-levels (accessed on 29 November 2021). 
Fichter, Klaus, and Irina Tiemann. 2018. Factors influencing university support for sustainable entrepreneurship: Insights from explorative case studies. Journal of Cleaner Production 175: 512-24. [CrossRef]

Fishbein, Martin. 1967. A behavior theory approach to the relations between beliefs about an object and the attitude toward the object. In Readings in Attitude Theory and Measurement. Edited by Martin Fishbein. New York: John Wiley \& Sons, pp. $389-400$.

Fishbein, Martin, and Icek Ajzen. 1975. Belief, Attitude, Intention, and Behavior: An Introduction to Theory and Research. Reading: Addison-Wesley.

Garavan, Thomas, Naomi Birdthistle, Barra Ó Cinnéide, and Chris Collet. 2010. Entrepreneurship education in the republic of Ireland: Context, opportunities and challenges. In Handbook of Research in Entrepreneurship Education, Volume 3: International Perspectives. Edited by Alain Fayolle. Cheltenham: Edward Elgar Publishing, pp. 225-47.

Gustomo, Aurik, Sri Herliana, Wawan Dhewanto, and Astri Ghina. 2017. Building a Conceptual Framework of Entrepreneurial Competencies: The Ontological, Epistemological, and Methodological View. International Journal of Applied Business and Economic Research 15: 191-201.

Hesselbarth, Charlotte, and Stefan Schaltegger. 2014. Education future change agents for sustainability-learnings from the first sustainability management master of business administration. Journal of Cleaner Production 62: 24-36. [CrossRef]

Hsieh, Chi-Ming, Sung Hee Park, and Regina McNally. 2016. Application of the Extended Theory of Planned Behavior to Intention to Travel to Japan Among Taiwanese Youth: Investigating the Moderating Effect of Past Visit Experience. Journal of Travel $\mathcal{E}$ Tourism Marketing 33: 717-29. [CrossRef]

Irwin, Julie, and Gary McClelland. 2001. Misleading Heuristics and Moderated Multiple Regression Models. Journal of Marketing Research 38: 100-9. [CrossRef]

Joensuu-Salo, Sanna, Elina Varamäki, and Anmari Viljamaa. 2015. Beyond intentions—What makes a student start a firm? Education + Training 57: 853-73. [CrossRef]

Joensuu-Salo, Sanna, Anmari Viljamaa, and Elina Varamäki. 2020. Do intentions ever die? The temporal stability of entrepreneurial intention and link to behavior. Education + Training 62: 325-38. [CrossRef]

Krueger, Norris, and Alan Carsrud. 1993. Entrepreneurial intentions: Applying the theory of planned behavior. Entrepreneurship E Regional Development 5: 315-30.

Krueger, Norris, Michael Reilly, and Alan Carsrud. 2000. Competing models of entrepreneurial intentions. Journal of Business Venturing 15: 411-32. [CrossRef]

Kuratko, Donald. 2011. Entrepreneurship theory, process, and practice in the 21st century. International Journal of Entrepreneurship and Small Business 13: 8-17. [CrossRef]

La Barbera, Francesco, and Icek Ajzen. 2021. Moderating role of perceived behavioral control in the theory of planned behavior: A preregistered study. Journal of Theoretical Social Psychology 5: 35-45. [CrossRef]

Lans, Thomas, Vincent Blok, and Renate Wesselink. 2014. Learning apart together: Towards an integrated framework for sustainable entrepreneurship competence in higher education. Journal of Cleaner Production 62: 37-47. [CrossRef]

Lave, Jean. 2009. The practice of learning. In Contemporary Theories of Learning: Learning Theorists ... in Their Own Words. Edited by Knud Illeris. London: Routledge, pp. 200-8.

Liñán, Francisco, and Yi-Wen Chen. 2009. Development and Cross-Cultural Application of a Specific Instrument to Measure Entrepreneurial Intentions. Entrepreneurship Theory and Practice 33: 593-617. [CrossRef]

Lortie, Jason, and Gary Castogiovanni. 2015. The theory of planned behavior in entrepreneurship research: What we know and future directions. International Entrepreneurship and Management Journal 11: 935-57. [CrossRef]

Maalaoui, Adnane, Charles Perez, Gaël Bertnand, Myriam Razgallah, and Rony Germon. 2018. "Cruel intention" or "entrepreneurial intention": What did you expect? An overview of research on entrepreneurial intention-An interactive perspective. In A Research Agenda for Entrepreneurial Cognition and Intention. Edited by Malin Brännback and Alan Carsrud. Cheltenham: Edward Elgar, pp. 7-46.

Martinez, Lourdes, and Nehama Lewis. 2016. The Moderated Influence of Perceived Behavioral Control on Intentions among the General U.S. Population: Implications for Public Communication Campaigns. Journal of Health Communication 21: 1006-15. [CrossRef] [PubMed]

Masciarelli, Francesca, and Simona Leonelli. 2020. Sustainable Entrepreneurship. How Entrepreneurs Create Value from Sustainable Opportunities. Bingley: Emerald Publishing Limited.

Mitchelmore, Siwan, and Jennifer Rowley. 2010. Entrepreneurial competencies: A literature review and development agenda. International Journal of Entrepreneurial Behavior \& Research 16: 92-111.

Moya-Clemente, Ismael, Gabriela Ribes-Giner, and Joana Carolina Chaves-Vargas. 2021. Sustainable entrepreneurship: An approach from bibliometric analysis. Journal of Business Ecoomics and Management 22: 297-319. [CrossRef]

Mulder, Martin, Judith Gulikers, Harm Biemans, and Renate Wesselink. 2009. The new competence concept in higher education; error or enrichment? Journal of European Industrial Training 33: 755-70. [CrossRef]

Nowiński, Witold, Mohamed Haddoud, Drahoslav Lančarič, Dana Egerová, and Csilla Czeglédi. 2019. The impact of entrepreneurship education, entrepreneurial self-efficacy and gender on entrepreneurial intentions of university students in the Visegrad countries. Studies in Higher Education 44: 361-79. [CrossRef]

Nunnally, Jum. 1978. Psychometric theory, 2nd ed. New York: McGraw-Hill. 
Osagie, Efosa, Renate Wesselink, Vincent Blok, Thomas Lans, and Megan Mulder. 2016. Individual competencies for corporate social responsibility: A literature and practice perspective. Journal of Business Ethics 135: 233-52. [CrossRef]

Ploum, Lisa, Vincent Blok, Thomas Lans, and Onno Omta. 2018. Toward a Validated Competence Framework for Sustainable Entrepreneurship. Organization \& Environment 31: 113-32.

Podsakoff, Philip Michael, Scott MacKenzie, Jeong-Yeon Lee, and Nathan Podsakoff. 2003. Common Method Biases in Behavioral Research: A Critical Review of the Literature and Recommended Remedies. Journal of Applied Psychology 88: 879-903. [CrossRef] [PubMed]

Rieckmann, Marco. 2012. Future-oriented higher education: Which key competencies should be fostered through university teaching and learning? Futures 44: 127-35. [CrossRef]

Sawang, Sukanlaya, Yyan Sun, and Siti Aisyah Salim. 2014. It's not only what I think but what they think! The moderating effect of social norms. Computers \& Education 76: 182-89. [CrossRef]

Shepherd, Dean, and Holger Patzelt. 2011. The new field of sustainable entrepreneurship: Studying entrepreneurial action linking 'what is to be sustained' with 'what is to be developed'. Entrepreneurship: Theory and Practice 35: 137-63.

Shin, Yeon Ho, Seung Eun Jung, Jinyoung Im, and Kimberly Severt. 2020. Applying an extended theory of planned behavior to examine state-branded food product purchase behavior: The moderating effect of gender. Journal of Foodservice Business Research 23: 358-75. [CrossRef]

Stubbs, Wendy. 2017. Sustainable Entrepreneurship and B Corps. Business Strategy and the Environment 26: 331-344. [CrossRef]

Thomassen, Mette Lindahl, Karen Williams Middleton, Michael Breum Ramsgaard, Helle Neergaard, and Lorraine Warren. 2020. Conceptualizing context in entrepreneurship education: A literature review. International Journal of Entrepreneurial Behavior $\mathcal{E}$ Research 26: 863-86.

Thompson, Edmund. 2009. Individual Entrepreneurial Intent: Construct Clarification and Development of and Internationally Reliable Metric. Entrepreneurship Theory and Practice 3: 669-94. [CrossRef]

Umeh, Kanayo, and Reema Patel. 2004. Theory of planned behaviour and ecstasy use: An analysis of moderator-interactions. British Journal of Health Psychology 9: 25-38. [CrossRef]

United Nations. 2021. Sustainable Development Goals. Available online: https://sdgs.un.org/goals (accessed on 29 November 2021).

Vuorio, Anna Maija, Kaisu Puumalainen, and Katharina Fellnhofer. 2018. Drivers of entrepreneurial intentions in sustainable entrepreneurship. International Journal of Entrepreneurial Behavior E Research 24: 359-81. [CrossRef]

Wagner, Marcus. 2012. Ventures for the public good and entrepreneurial intentions: An empirical analysis of sustainability orientation as a determining factor. Journal of Small Business and Entrepreneurship 25: 519-31. [CrossRef]

Wan, Calvin, Geoffrey Qiping Shen, and Stella Choi. 2018. The moderating effect of subjective norm in predicting intention to use urban green spaces: A study of Hong Kong. Sustainable Cities and Society 37: 288-97. [CrossRef]

Wang, Chang, Jinhe Zhang, Peng Yu, and Huan Hu. 2018. The theory of planned behavior as a model for understanding tourists' responsible environmental behaviors: The moderating role of environmental interpretations. Journal of Cleaner Production 194: 425-34. [CrossRef]

Welter, Friederike, William Gartner, and Mike Wright. 2016. The context of contextualizing contexts. In A Research Agenda for Entrepreneurship and Context. Edited by Friederike Welter and William Gartner. Cheltenham: Edward Elgar, pp. 1-15.

Wesselink, Renate, Cees De Jong, and Harm Biemans. 2010. Aspects of competence-based education as footholds to improve the connectivity between learning in school and in the workplace. Vocations and Learning 3: 19-38. [CrossRef]

Wesselink, Renate, Vincent Blok, Sebastiaan van Leur, Thomas Lans, and Domenico Dentoni. 2015. Individual competencies for managers engaged in corporate sustainable management practices. Journal of Cleaner Production 106: 497-506. [CrossRef]

Wood, Robert, and Albert Bandura. 1989. Social Cognitive Theory of Organizational Management. Academy of Management Review 14: 361-84. [CrossRef]

Yang, Yuha, Jin Nam Choi, and Kyungmook Lee. 2018. Theory of Planned Behavior and Different Forms of Organizational Change Behavior. Social Behavior and Personality 26: 1657-72. [CrossRef]

Ybarra, Oscar, and David Trafimow. 1998. How priming the private self or collective self affects the relative weights of attitudes and subjective norms. Personality and Social Psychology Bulletin 24: 362-70. [CrossRef]

Yzer, Marco. 2012. Perceived Behavioral Control in Reasoned Action Theory A Dual-Aspect Interpretation. The Annals of the American Academy of Political and Social Science 640: 101-17. [CrossRef]

Yzer, Marco, and Bas van den Putte. 2014. Control perceptions moderate attitudinal and normative effects on intention to quit smoking. Psychology of Addictive Behaviors 28: 1153-61. [CrossRef] 